Samo Skralovnik

\title{
Predgovor: spominjajte se in učite svoje sinove!
}

\author{
Preface: Remember and Teach Your Children!
}

\begin{abstract}
Vtisnite si te moje besede $v$ srce in $v$ dušo, privežite si jih za znamenje na roko in naj vam bodo za čelni nakit med očmi.
\end{abstract}

Nikoli ne bomo vedeli, kolikokrat so ustnice judovskih vernikov šepetaje izrekale vrstico iz Pete Mojzesove knjige $(11,18)$, preden se je ta dobesedno vtisnila $\mathrm{v}$ judovsko kolektivno zavest kot nekakšen bivanjski vzorec. Eno bolj znanih svetopisemskih vrstic, ki jo zna na izust domala vsak Jud, ki je skrita v sleherni mezuzi in tefilinu, lahko razumemo kot »veliko zapoved «, imperativ spominjanja. Vsak tefilin, molitveni jermeni, ali talit, molitveno pokrivalo, ali kakšen drug judovski predmet ima eno samo funkcijo je znak in opomnik Božje zaveze. Celotna judovska samobitnost, in posledično tudi krščanska, ki ji je uspelo kljubovati različnim zgodovinskim izzivom, se napaja in hrani iz istega vira: iz spomina in spominjanja.

Spominjanje pa v judovsko-krščanskem kontekstu samo po sebi nima nikakršne vrednosti, če ne vodi v določen način življenja. Zgodovinska resničnost je sicer predpostavljena, pa vendar spomin vsebuje tako razsežnost rekonstrukcije preteklosti kot tudi razsežnost ponavzočanja. Preteklost, podobno kot spisi Svetega pisma, mora postati sedanja resničnost, ki oblikuje vsakodnevno življenje vsakega posameznika in skupnosti. V nasprotnem primeru je vrednost take preteklosti oz. Svetega pisma antikvariatna. 
Vtisnite si te moje besede $v$ srce in $v$ dušo ...

Ta številka revije Edinost in dialog, ki zaključuje obeleževanje 50. obletnice ustanovitve Enote Teološke fakultete v Mariboru, v prvem delu prinaša kritično-analitične orise pedagoških in znanstvenoraziskovalnih sledi profesorjev, povezanih z njo. Zahodni človek je, kakor goreče razlaga prof. Aleksič, čas »vprostoril«, tj. ga stisnil v prostor, utesnil in mu vzel značaj dinamičnosti. Takšno dojemanje časa, razlikovanje med preteklostjo, sedanjostjo in prihodnostjo, je bolj nekaj prostorskega (preteklost je "za" nami, prihodnost "pred «nami) kakor vsebinskega. Čas v bibličnem smislu pa je »večno stvarjenje«. Predstavljene posameznike zato razumemo kot žive gradnike, na katerih in iz katerih živi skupnost danes. Zato so ti danes na prav poseben in hkrati neizbrisen in nenadomestljiv način vtisnjeni $\mathrm{v}$ podobo enote, $\mathrm{v}$ njeno znanstvenoraziskovalno in pedagoško ter širše kulturno srce in dušo.

... privežite si jih za znamenje na roko ...

Vsi predstavljeni posamezniki so svoje življenje, življenjske moči in svojo desnico zastavili za pedagoško in znanstvenoraziskovalno delo (na enoti). To je bilo njihovo znamenje na roki, njihova sol (zaveze), zaradi katere niso in ne morejo ostati skriti, čeravno niso več med nami.

Uvodoma dr. Pevec Rozmanova predstavi nekatere doslej manj znanje vidike življenjske poti dr. Trstenjaka in pokaže na aktualnost njegove antropologije in pomen terapevtsko svetovalnega dela predvsem $\mathrm{v}$ času, ko se sodobni človek v stiski srečuje z različnimi terapevtskimi praksami in izbira med njimi. Dr. Skralovnik predstavi biblicista dr. Aleksiča, znanilca in prinašalca biblične pomladi v slovenskem prostoru. Na njegovo delo je močno vplivalo dogajanje v Cerkvi na področju uradnega odnosa Katoliške cerkve, tj. katoliške eksegeze, do Svetega pisma, saj v vsaki razpravi omenja, razlaga in se sklicuje na pomembne papeške dokumente tistega časa. Vsi ti dokumenti imajo izrazito polemično oz. apologetično naravo in jih lahko razumemo, podobno kot večino Aleksičevih razprav, kot odgovor na izzive časa. 
Dr. Turnšek oriše teološko delo dr. Plemenitaša, ki je slovenski prostor seznanjal s svežimi teološkimi tokovi, nastajajočimi po drugem vatikanskem vesoljnem cerkvenem zboru. V tem smislu je pripadal t. i. »Grmičevemu krogu«, katerega »vodjo«, dr. Grmiča, v družbenopolitičnem kontekstu prikaže dr. Maver. Svojevrstno "pomlad« teološke misli v Mariboru in na Slovenskem je omogočilo ravno (njegovo) takratno navdušenje nad drugim vatikanskim cerkvenim zborom in »vzhodno politiko« papeža Pavla VI. $\mathrm{V}$ ta tok lahko prištejemo tudi dr. Steinerja, ki ga predstavi g. Ložar, in sicer kot moralnega teologa drugega vatikanskega koncila, ki je moralni teologiji na Slovenskem pomagal, da se je začela odmikati od pretirano pravniškega pogleda na moralne norme in moralne zakone. Predstavitev osebnosti enote zaključi raziskava dr. Krajnc-Vrečkove, ki osvetljuje življenje in delo teologa in literarnega zgodovinarja dr. Rajhmana. Kot priznani trubarolog s svojim delom na področju slovenske protestantike spada med pomembnejše ekumenske delavce na Slovenskem v drugi polovici 20. stoletja.

\section{... in naj vam bodo za čelni nakit med očmi}

Rabin Johanan ben Zakaj je nekoč svojim učencem dejal: »Pojdite ven in poglejte, katera pot je dobra in se je mora človek okleniti.« Rabi Eliezer mu odvrne: »Dobro oko.«(mAv 2,13) Pot v bibličnem jeziku predstavlja življenjsko usmeritev, držo, pisana z veliko začetnico pa predstavlja specifično krščansko življenje. Prvi kristjani so bili tako označeni kot "privrženci Poti«(Apd 9,2). Vendar pa »sedeti ob Poti«(Mr 10,46; Lk 18,35) še ne zadostuje, kot nam z vso jasnostjo pokažejo evangeljske zgodbe o slepoti. Prispodoba središča osebe so oči, te so tiste, ki usmerjajo pogled in kasneje korak, ustvarjajo vizijo in so zato seme prihodnosti. V nadaljevanju številke tako predstavljamo različna tematska "semena prihodnosti«, različne aktualne izzive teologije kot njeno perspektivo prihodnosti.

Dr. Rezarjeva najprej predstavi Slomškovo prizadevanje, da bi materni jezik postavil v temelj vsake izobrazbe, še zlasti bogoslovne. Njegovo jezikovno delo je imelo dolgoročne vplive, saj je z njim pripravljal temelje za nadaljnji razvoj dogodkov ob prestavitvi škofijskega sedeža in začetkih visokega šolstva v Mariboru. Njegovo razumevanje slovenščine pa ostaja aktualno tudi danes pri sodobnem jezikovnem načrtovanju maternega jezika v slovenskem izobraževalnem sistemu - tudi na visokošolski stopnji. 
To potrjuje prispevek dr. Radića, ki se zazre še dlje v preteklost in na eni strani poudari pomen teološkega jezika apostola Pavla kot paradigmatskega modela komuniciranja in razumevanja, hkrati pa ostaja aktualen, saj lahko Pavlov jezik, ki je vedno imel velike praktične posledice na področju krščanskega poslanstva in življenja Cerkve, služi kot paradigma teološkega govora in komunikacije Cerkve s sodobnim svetom. Dr. Matjaž nadaljuje Pavlovo misel in obravnava biblični model skupnosti in reševanja konfliktov ter iskanja edinosti ob srečevanju različnih kultur. Ne novega življenja ne oznanjevanja evangelija ni mogoče živeti kot posameznik, temveč le kot občestvo. Zato je po Pavlu tudi danes glavno poslanstvo Cerkve, da s povezovanjem in vključevanjem ustvarja prostor, kjer se lahko razodeva novo - občestveno življenje (2 Kor 13,13).

Dr. Debevec z analizo svetopisemskih besedil potrjuje tezo o prisotnosti in presenetljivem bogastvu prostorskih podob, ki besedilu niso zgolj v okras, marveč so pogosto uporabljene kot nosilci vsebin. Dr. Avsenik Nabergojeva pa, nasprotno, svoje pero usmeri v človekovo »notranjo zgradbo« $\mathrm{v}$ razponu od najosnovnejših čutnih in čustvenih vzgibov do pretanjenih duhovnih doživetij in vizij. S poudarkom na notranjem izkustvu duhovne narave, kot ga najdemo v Svetem pismu in v poznejših literarnih zapisih o religioznem izkustvu, pokaže, da le celosten pristop omogoča strokovni diskurz.

V sklepnem delu revije dr. Saje v članku v italijanščini predstavi Teološko fakulteto kot znanstveno in vzgojno visokošolsko ustanovo, katere narava je $\mathrm{v}$ primerjavi z drugimi fakultetami posebna $\mathrm{v}$ tem, da sodeluje pri oznanjevalni službi Cerkve. Teologija je znanost, v kateri se zrcali katoliški nauk, in temelji na pravici do svobode verovanja. Ta se od države do države lahko razlikuje. Mag. Valentan v svoji razpravi tako prikaže različne oblike odnosov med državo in verskimi skupnostmi, skozi katere se zrcali stopnja varovanja pravice do verske svobode, s poudarkom na slovenskem prostoru.

Na koncu dr. Slatinek obravnava vprašanje obhajanja v mešanem zakonu z luteranom. Sveto obhajilo pod podobo kruha je za Katoliško cerkev zakrament dobrotljivosti, vez ljubezni in "znamenje edinosti« (signum unitatis) kristjanov, a je svetemu obhajilu lastno tudi to, da je zakrament tistih, 
ki so v polnem občestvu s Cerkvijo. To kaže na potrebo po poglobljeni teološki in ekumenski razpravi tudi v prihodnosti.

Učite jih svoje sinove tako, da jim jih govorite, ko bivaš v svoji hiši in ko hodiš po poti, ko legaš in ko vstajaš!

Revija Edinost in dialog z bogatim naborom prispevkov, s hvaležnim pogledom $\mathrm{v}$ preteklost, s spominjanjem, ki je izhodišče prihodnosti, stopa na "pot« in se ne le včlenja v "polpreteklo« dogajanje v mariborskem kulturnem prostoru, temveč iz tega vira gradi (svojo) krščansko identiteto.

V Svetem pismu takoj za vrstico, s katero smo začeli to uvodno razmišljanje, sledi drug pomemben imperativ, Učite to svoje sinove! (5 Mz 11,19), imperativ prenašanja tega spomina na naslednje generacije. Ta je enako pomemben kot spominjanje in predstavlja le drugi pol iste resničnosti. Tako nekateri Judje pravijo, da Jud ni toliko tisti, ki je rojen materi Judinji, kot pa tisti, ki mu uspe po teh načelih nenehno vzgajati sebe in svojega sina, se pravi, da ima živ odnos z Bogom in da ta zaklad svoje identitete zmore predati tudi prihodnjemu rodu. Obstaja tudi rek: »Poučevanje otrok se ne sme opustiti niti zaradi obnavljanja templja."

Če lahko torej na koncu upamo, da je prva zapoved spominjanja (tudi s to številko revije) »obkljukana«, pa nam ostaja še druga, ki naslednja desetletja, morda stoletja, teologijo zavezuje k njeni najodličnejši nalogi: ohranjanju študija teologije v Mariboru tudi v prihodnosti. 